\title{
MAJOR CONTEMPORARY APPROACHES TO THE ANALYSIS OF THE VIETNAMESE SIMPLE CLAUSE
}

\author{
Nguyen Thi Tu Trinh", , Phan Van $\mathrm{Hoa}^{2}$, Tran Huu Phuc ${ }^{3}$ \\ ${ }^{1}$ Department of English, College of Transport II, 28 Ngo Xuan Thu, Lien Chieu, Danang, Vietnam \\ ${ }^{2}$ Department of International Education, University of Danang, \\ 41 Le Duan, Hai Chau, Danang, Vietnam \\ ${ }^{3}$ University of Foreign Language Studies, University of Danang, \\ 131 Luong Nhu Hoc, Khue Trung, Cam Le, Danang, Vietnam
}

Received 07 April 2017

Revised 31 October 2017; Accepted 29 November 2017

\begin{abstract}
Clause as a grammatical category has been at the centre of attention throughout most of the history of linguistics in Vietnam and has caused a lot of troubles for analysis and interpretation. Great efforts have been made to shed light on this matter. There is, however, no consensus among Vietnamese linguists on clause analysis and interpretation because each of them seems to work on clause analysis in a variety of approaches using different frameworks. In this paper, we aim at investigating some major contemporary approaches to the analysis of the Vietnamese simple clause with our critical appraisals of each approach to provide readers with an overview of Vietnamese clause studies. The study reveals that at present structural approaches influenced by European and American structuralists such as Saussure and Bloomfield, and functional approaches influenced by Dik's functional grammar and Halliday's systemic functional grammar seem to be the dominant grammatical models for the analysis of the Vietnamese simple clause.
\end{abstract}

Keywords: comtemporary approaches, simple clause, structural approach, functional approach

\section{Introduction}

In recent years there has been a dramatic revival of interest in Vietnamese clause analysis. Many approaches are applied to analysis and interpretation of Vietnamese clauses. Yet, there is by no means a concensus among scholars and researchers. According to Nguyễn Văn Hiệp (2012), there is disagreement about Vietnamese clause interpretation since each linguist deals with clause analysis in a variety of approaches with different frameworks. There have been two major distinctive existing approaches, namely structural approach and functional approach, to Vietnamese clause analysis.

\footnotetext{
${ }^{*}$ Corresponding author. Tel.: 84-1656592033

Email: trinhtoeic@gmail.com
}

Structural approach is influenced by European traditional grammar, especially French grammar. Its analysis is based on SubjectPredicate structure. Many Vietnamese linguists like Phan Khôi (1955), Bùi Đức Tịnh (1952), Trương Văn Chình and Nguyễn Hiến Lê (1963) applied this traditional SubjectPredicate structure to analysis of Vietnamese clauses while functional approach is based on Functional Grammar by Dik (1989) and An Introduction to Functional Grammar by Halliday (1994, 2004, 2014). The late 20th century witnessed the flourishment of systemic functional grammar (SFG) and its great influence on language research and teaching in Vietnam. This is a new trend in modern Vietnamese grammar which helps us solve some problems in interpreting and analyzing 
a clause that traditional grammar cannot do. This analysis of the clause is based on Theme-Rheme structure (clause as message), Mood structure (clause as exchange) and Transitivity system (clause as representation). In addition, many studies have been carried out to interpret Vietnamese clauses on the account of functional grammar. This paper aims at exploring and critically discussing these two contemporary approaches to the analysis of Vietnamese simple clauses and an attempt is made to distinguish between areas in which there is unanimous agreement about principles and analyzes and areas in which there is considerable disagreement.

Although many studies have focused on analyzing the Vietnamese clause both in terms of syntax (form) and meaning (function) (e.g. Phan Khôi, 1955; Bùi Đức Tịnh, 1952; Diệp Quang Ban, 2006, 2013; Hoàng Văn Vân, 2002, 2012; Cao Xuân Hạo, 1991; Nguyễn Văn Hiệp, 2009; and Bùi Minh Toán, 2012), each analyzes and interprets the clause in a different way, using a diferent theoretical framework. The result is that clause analysis appears to be a very complex process. Bearing in mind the complexity of the problem, in this study, an attempt is made to explore how structural and functional approaches are utilized to analyze the Vietnamese simple clause. As a way of start, we will first discuss the strutural approach to the analysis of the clause. Then two functional approaches: Dik's approach and Halliday's approach applied to the analysis of the Vietnamese simple clause are presented in more detail.

\section{Structural approach to clause analysis}

According to Hoàng Văn Vân (2012: 25), the study of Vietnamese grammar is divided into three periods: (i) Protogrammatics of Vietnamese (1850s-1930s); (ii) pre-structuralist and structuralist description of Vietnamese (1930s-1980s) and (iii) functionalist description of
Vietnamese (1980s-present). It is found, however, that not much of the literature on the proto-grammatics of Vietnamese is currently available. Therefore, in the section that follows, we will focus on the second period which saw great influences of French, American and European structural interpretation of Vietnamese simple clauses.

\subsection{French structural approach to the} analysis of the Vietnamese simple clause

The structural approach to the Vietnamese clause analysis is strongly influenced by European traditional grammar, especially French grammar. In this tradition, the clause is divided into what are referred to as Subject and Predicate. Many Vietnamese traditional linguists like Phan Khôi (1955), Bùi Đức Tịnh (1952) applied this Subject-Predicate structure to analyzing Vietnamese clauses. According to Nguyễn Văn Hiệp (2012), traditional grammar has achieved a dominant position in Vietnamese grammar for a long time. It is no exaggeration to say that, in the early period (1850-1935), most Vietnamese grammarians adopted the model of grammar given by French scholars. Throughout the country, a great number of grammatical textbooks written under traditional perspective were used in schools at all levels, from primary to tertiary. Because of its pedagogical advantages, traditional grammar is also labeled as "school grammar" or "pedagogical grammar", traditional grammar developed a great deal of grammatical terminologies to name not only grammatical units but also their grammatical functions such as word, phrase, clause, sentence and subject, predicate, object, direct object, indirect object, adverb, modifier and many others. Concerning grammatical functions one can see that Subject and predicate are seen as the main elements of the clause whilst object, direct object, indirect object, adverb, modifier belong to optional and supportive elements. At lower level, 
modifier, object, direct object and indirect objects are embedded in the Subject-Predicate structure. Adverb and thematic elements are within Subject-Predicate structure while conjunction, exclamation, modal and apostrophe (vocative) are completely isolated from structure of clauses. The elements of structural analysis of the Vietnamese clause can be illustrated in Figure 1. in Vietnamese. However, making a distinction between clause (cú) and sentence (câu) is fairly problematic and debatable. The term sentence (câu) is preferably used at that time. Trần Trọng Kim et al (1940: 27) define sentence as being "formed by a proposition expressing a complete thought or by two and more propositions." They classify three kinds of propositions: independent, main and

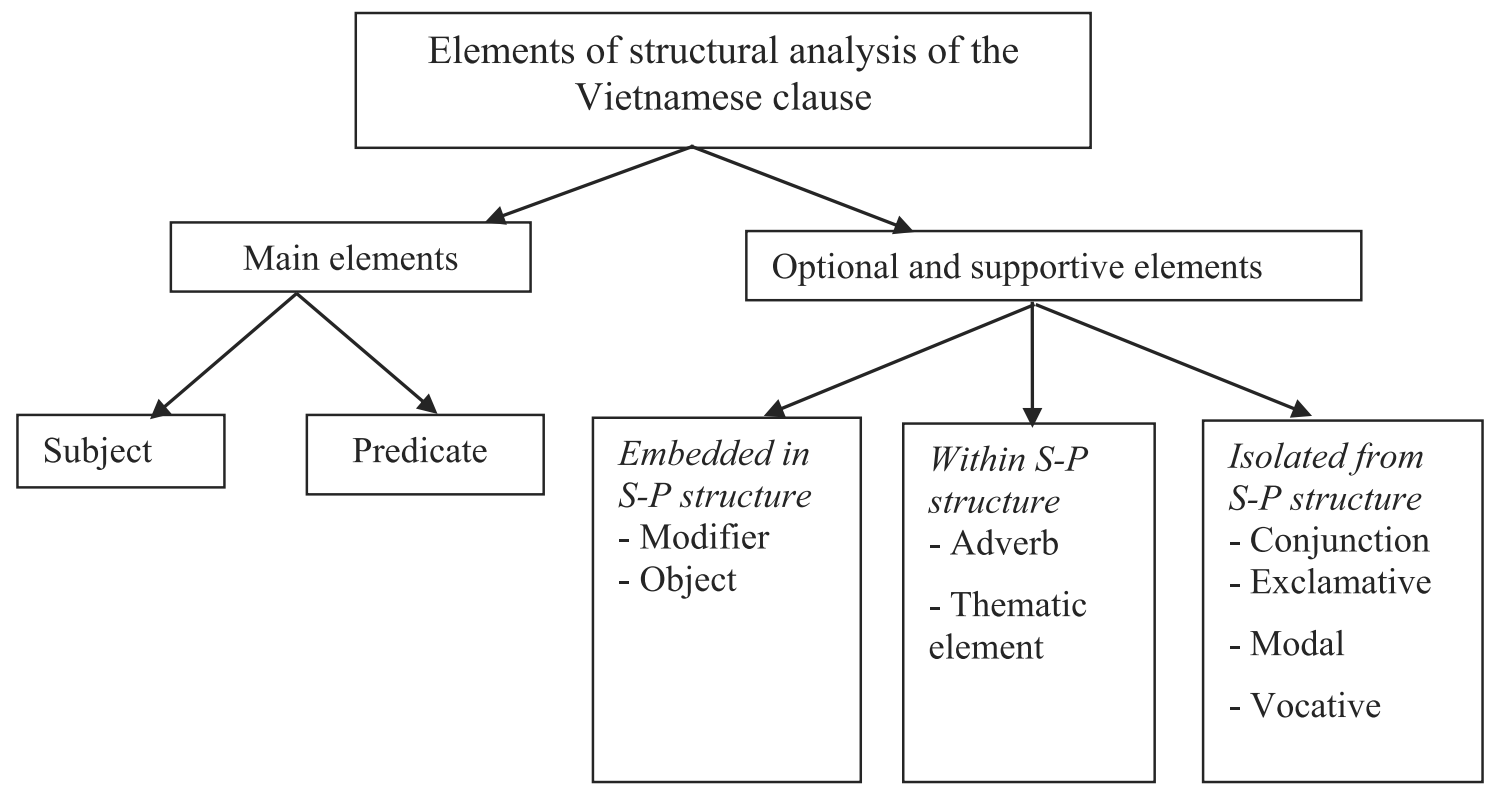

Figure 1. The elements of structural analysis of the Vietnamese simple clause

It is arguable that French structural approach pays more attention to morphology than syntax and it focuses on the methods or rules of sentence construction rather than definition of sentence (see Hoàng Văn Vân, 2002, 2012). There do exist translation equivalents of clause (cú) and sentence (câu) subordinate. Sentence in their view is seen as a composition of a cluster of propositions with a main proposition preceded and /or followed by one or more subordinate propositions.

According to Đào Minh Thư et al (2009), the structural analysis of clauses can be shown like the following:

(1)

\begin{tabular}{|c|c|c|}
\hline $\begin{array}{l}\text { Một gói thuốc lá thơm và một bao diêm } \\
\text { A packet tobacco fragrant and a box match }\end{array}$ & $\begin{array}{l}\text { đặt } \\
\text { put }\end{array}$ & $\begin{array}{cl}\text { ở bên cạnh cái đĩa gạt tàn thuốc. } \\
\text { next to } & \text { ashtray cigarrette ends }\end{array}$ \\
\hline Subject & Predicate & Adverb-place \\
\hline
\end{tabular}

'A packet of fragrant tobacco and a box of matches were put next to an ashtray' (Nam Cao, 1965) 
(2)

\begin{tabular}{|c|c|c|}
\hline $\begin{array}{c}\text { Tôi } \\
\mathrm{I}\end{array}$ & $\begin{array}{c}\text { nghĩ đến } \\
\text { think of }\end{array}$ & $\begin{array}{c}\text { mấy quyển sách quý của tôi. } \\
\text { some book precious of I }\end{array}$ \\
\hline Subject & Predicate & \multicolumn{2}{|c|}{ Object } \\
\hline
\end{tabular}

'I think of my valuable books.'

(Nam Cao, 1965)

(3)

\begin{tabular}{|c|c|c|c|c|c|}
\hline $\begin{array}{c}\text { Thưa ông, } \\
\text { Sir }\end{array}$ & $\begin{array}{c}\text { bốn cháu của con } \\
\text { four PRN of PRN }\end{array}$ & $\begin{array}{c}\text { nhờ trời } \\
\text { thanks god }\end{array}$ & $\begin{array}{c}\text { vẫn } \\
\text { still }\end{array}$ & $\begin{array}{c}\text { khỏe mạnh } \\
\text { fine strong }\end{array}$ & $\begin{array}{c}\text { cả. } \\
\text { modality }\end{array}$ \\
\hline Apostrophe & Subject & Modal element & Modifier & Predicate & Modifier \\
\hline
\end{tabular}

'Sir, thank god, all my four children are still fine.' (Ma Văn Kháng, 1985)

These examples in (1) and (2) show that Subject and Predicate are the main and compulsory elements in Vietnamese simple clauses whilst adverbs and objects are available and optional. According to Nguyễn Hồng Cổn (2009), the viewpoint that the syntax of Vietnamese simple clauses must have Subject-Predicate elements is commonly shared among Vietnamese linguists. Moreover, some researchers like Nguyễn Kim Thản (1964), Hoàng Trọng Phiến (1980), Diệp Quang Ban (1984) Lê Xuân Thại (1995) also other terms even if we face challenges of analyzing Vietnamese empty words (see Trần Kim Phượng, 2010). However, structural approach has its own shortcomings in analyzing Vietnamese simple clauses. Let us consider the following examples:

(4) Giữa nhà treo một lá cờ đỏ sao vàng.

(5) Ở trong thắp hàng trăm hàng nghìn đèn nến.

Structural analysis of these two examples is illustrated as follows:

(4')

\begin{tabular}{|c|c|c|c|}
\hline $\begin{array}{l}\text { Giữa nhà } \\
\text { Middle of house }\end{array}$ & $\begin{array}{c}\text { treo } \\
\text { hang }\end{array}$ & $\begin{array}{l}\text { một lá cờ } \\
\text { a flag }\end{array}$ & $\begin{array}{c}\text { đỏ sao vàng. } \\
\text { red star gold }\end{array}$ \\
\hline Subject & Predicate & Object & Modifier \\
\hline
\end{tabular}

'In the middle of the house, there is a red flag with a gold star.' (Bùi Minh Toán, 2012: 264)

(5')

\begin{tabular}{|c|c|l|}
\hline $\begin{array}{c}\text { Ở trong } \\
\text { Inside }\end{array}$ & $\begin{array}{c}\text { thắp } \\
\text { light }\end{array}$ & $\begin{array}{l}\text { hàng trăm hàng nghìn đèn nến. } \\
\text { hundreds thousands lights candles }\end{array}$ \\
\hline Subject & Predicate & Object \\
\hline
\end{tabular}

'Thousands and thousands of candles were burning in countless rows inside.'

(Bùi Minh Toán, 2012: 264)

show their interest in this approach. Structural approach applied to analyzing the Vietnamese simple clause has its own strengths and shortcomings. To a certain extent, the subject and predicate elements are very familiar to students and researchers. This approach is early studied and it is possible to build up a comprehensive framework to interpret Vietnamese simple clauses in terms of Subject, Predicate, Object, Modifiers, Adverbs and
Nguyễn Văn Hiệp (2012) offers two approaches to interpreting these two clauses, namely structural and functional approach. In the former approach, "giữa nhà" (in the middle of the house) and "ở trong" (inside) function as Subject, "treo" (hang) and "thắp" (light) function as Predicates. In contrast, in the latter approach "giữa nhà" (in the middle of the house) and "ở trong" (inside) function as Circumstance - Location and the two clauses 
can be considered Existential processes processes of existence. We will discuss functional approach in details in Section 3. We completely agree with his functional analysis seeing these two clauses as Existential clauses. Nevertheless, to a certain extent, we are not satisfied with his structural interpretation. Since it is important to note that "giữa nhà" (in the middle of the house) and "ở trong" (inside) are prepositional phrases and it does not make sense to interpret them as subjects in (4) and (5). Trần Kim Phượng (2010), on the other hand, suggests that on account of structural approach, they should be considered as Vietnamese special clauses in which giữa nhà" (in the middle of the house) and "ở trong" (inside) are interpreted as Adverbs, "treo" (hang) and "thắp" (light) function as Predicate and they are Vietnamese typical special clauses without subjects. We share a common view on this matter with Phượng. It is clear that there are controversial debates and unsatisfying interpretation of these cases if structural approach is applied to analyze Vietnamese clauses. Consider other Vietnamese simple clauses:
However, what will occur if we use syntactic behavior (Nguyễn Văn Hiệp, 2012) to rewrite (6) and (7).

(6') Cái đầu tóc đỏ được ngắm nghía bởi ông thầy.

(Vũ Trọng Phụng, 1938)

'His red hair is being stared by the fortune teller'

(7’) Thầy đồ Cóc được bấm bụng nhịn cười bởi tôi.

(Tô Hoài, 1941)

'The teacher $\mathrm{Coc}$ is suppressed my laughter by me'

The rewritten examples (6') and (7') are known as Vietnamese passive voice. In Vietnamese, we quickly see that (6') is probably acceptable while ( $\left.7^{\prime}\right)$ sounds completely odd and unnatural. From structural approach, it is impossible to offer a satisfying and comprehensive explanation since both "cái đầu tóc đỏ" (his red hair) and "thầy đồ Cóc" (teacher Coc) are interpreted as objects in these two examples above. Efforts to figure out an adequate explanation for these two examples are made by functionalists. According to semantic functions, "cái đầu tóc đỏ" (his red hair) and "thầy đồ Cóc" (teacher

(6)

\begin{tabular}{|c|c|c|}
\hline $\begin{array}{c}\text { Ông thầy } \\
\text { Man teacher }\end{array}$ & $\begin{array}{c}\text { ngắm nghía } \\
\text { look at }\end{array}$ & $\begin{array}{c}\text { cái đầu tóc đỏ. } \\
\text { head hair red }\end{array}$ \\
\hline Subject & Verb & Object \\
\hline
\end{tabular}

'The fortune teller is staring at his red hair.'

(Vũ Trọng Phụng, 1938)

(7)

\begin{tabular}{|c|c|c|}
\hline $\begin{array}{c}\text { Tôi } \\
\text { I }\end{array}$ & $\begin{array}{c}\text { bấm bụng nhịn cười } \\
\text { press belly suppress laugh }\end{array}$ & $\begin{array}{c}\text { thầy đồ Cóc } \\
\text { teacher Coc }\end{array}$ \\
\hline Subject & Verb & Object \\
\hline
\end{tabular}

'I suppress my laughter at the teacher Coc'

(Tô Hoài, 1941)

Vietnamese scholars and researchers taking stances on structural approach consider (6) and (7) identical in terms of Vietnamese syntax with Subject-Verb-Object framework. In other words, in (6) and (7), what is seen is the syntactical representation of $\mathrm{S}-\mathrm{V}-\mathrm{O}$.
Coc) should be interpreted in terms of Target and Cause respectively. "cái đầu tóc đỏ" (his red hair) plays a role as a Target whilst "thầy đồ Cóc" (the master $\mathrm{Coc}$ ) is considered Cause. Functionalists base themselves on its different semantic functions of Subjects and 
objects to offer their explanation. They are examples of common linguistic phenomenon in Vietnamese that similar surface structures may reflect different semantic functions and in fact, there is never any such thing as complete paraphrase. As discussed above, despite its strengths, structural approach is somewhat limited and functional perspective appearing as a matter of fact makes some great contributions to clause analysis. We will look at functionalise approach to Vietnamese clause analysis in the next section.

\subsection{American structural approach to the} analysis of the Vietnamese simple clause

There was an increasing interest in Vietnamese in the United States during the World War II. If we do not count their interest meant for the military purposes during World War II, then Cornell, Georgetown, Yale and Columbia were the first universities offering Vietnamese as an academic course in the 1950s. 1951 onwards has seen strong impacts of American descriptive structuralist approach with such representative linguists as: Emeneau (1951), Thompson (1965), Nguyễn Đình Hòa (1997). In his Studies in Vietnamese (Annamese) Grammar, Emeneau (1951) discusses Vietnamese phonology, morphology and syntax. With the scope of this study, our attention is paid to his description of Vietnamese syntax. With respect to Vietnamese syntax, Emeneau uses the term "sentence" and his description of the Vietnamese sentence is primarily influenced by the eminent American structralistdescriptivist linguist Bloomfield (1887-1949). Emeneau states that predication has nucleus, namely: a predicate which may, but need not, be preceded by a subject. In other words, a predicate and subject are the two core elements of a sentence. It is suggestive that his descriptive approach is principally based on Bloomfield's account. Bloomfield (1933: 173) argues that "in a predication, the more object-like component is called the subject, the other part the predicate." Viewing Vietnamese grammar from Bloomfield's viewpoint, Emeneau notes that predicate is classified into two types: Substantive (including substantive or a substantive phrase) and Verb (including a verb and a verb phrase).

(8)

\begin{tabular}{|c|c|}
\hline $\begin{array}{c}\text { Hắn } \\
\text { He }\end{array}$ & $\begin{array}{c}\text { nuốt ừng ực. } \\
\text { swallow hard }\end{array}$ \\
\hline Subject & predicate \\
\hline
\end{tabular}

'He swallows hard.'

(Nam Cao, 1957)

The other impacts of the American descriptive/structuralist approach to the study of Vietnamese grammar can be seen in the American linguist Thompson's work A Grammar of Vietnamese in 1965 and his second edition named A Vietnamese Reference Grammar in 1987. Thompson employs immediate constitute analysis as the main method in his second edition for isolating components of the sentence as well as constituents of each component. Thompson (1987) argues that an utterance is analyzed into two or more parts which balance one another in the make-up of the whole. Each of these parts is then subjected to similar analysis, and so on until the level of single morphemes is reached and no further grammatical/ morphological division can be made.

Sentences, in Thompson's view, are subclassified into two main types: independent and dependent. Independent sentences are ones which occur in at least some environments as opening sentences in independent utterances, and dependent sentences are ones which occur only as second or later sentences in utterances or as opening sentences in responsive utterances. Thompson also discusses the notion of clause. According to Thompson, a clause is a predicate viewed as a sentence constituent. In other words, a clause is considered as an element of the sentence and a clause is 
either head or complement. When a clause occurs as head or as the whole of a certain sentence, it is the main clause. Conversely, when a clause appears as complement to other sentence elements, it is a subordinate clause.

In sum, Emeneau and Thompson made great attempts to interpret Vietnamese syntax from the viewpoints of the American structuralist/descriptivist approach. Their analysis of Vietnamese sentences involve subject and predicate. According to Hoàng Văn Vân (2012), their works are fairly comprehensive and descriptive at that time and Nguyễn Đình Hòa (in Thompson 1985: xv) states that "it remains far and away are the best thing available in English and this, most useful work for the greatest number of potential users."

\subsection{European structural approach to the} analysis of the Vietnamese simple clause

The publication of the work Khảo luận về ngũ pháp Việt Nam (a Treatise on the grammar of Vietnamese) by Trương Văn Chình và Nguyễn Hiến Lê (1963) marked a change in the influence of European structuralism upon the study of Vietnamese syntax. Trương Văn Chình và Nguyễn Hiến Lê offer the definition of sentence as follows:

Câu là một tổ hợp tiếng dùng để diễn tả một sự tình hay nhiều sự tình có quan hệ với nhau; tổ hợp từ này tự nó tương đối đầy đủ ý nghĩa, và không phụ thuộc về ngữ pháp vào một một tổ hợp nào khác. (A sentence is a complex of words used to express a state of affairs or many states of affairs which are closely related to one another; this complex of words is by itself relatively complete in meaning and is not grammatically dependent on any other complex of words)

(Trương Văn Chình và Nguyễn Hiến Lê, 1963: 476)

According to Trương Văn Chình và Nguyễn Hiến Lê (1963), a single sentence may consist of seven elements: (i) Subject, (ii) Predicate, (iii) Topic, (iv) Complement, (v)
Appositive (of the sentence), (vi) Subordinate and (vii) Sentence connector.

The study of Vietnamese grammar in North Vietnam in this period was primarily influenced by Saussure (1983)'s theory of language. Saussure, the founding figure of modern linguistics, made his mark by distinguishing langue from parole. Langue encompasses the abstract, systematic rules and conventions of a signifying system; it is independent of, and preexists, individual users. Langue involves the principles of language, without which no meaningful utterance, "parole", would be possible. Parole refers to the concrete instances of the use of langue. This is the individual, personal phenomenon of language as a series of speech acts made by a linguistic subject.

Hoàng Trọng Phiến (1980: 19) defines the sentence as follows:

Câu là ngữ tuyến được hình thành một cách trọn vẹn về ngữ pháp và ngữ nghĩa với một ngữ điệu theo các quy luật của một ngôn ngữ nhất định và là phương tiện diễ̂n đạt, biểu hiện tư tưởng về thực tế và về thái độ của người đối với hiện thực. (A sentence is a linguistic unit which has an independent grammatical structure (internal and external) and a terminal intonation; it expresses a relatively complete thought and may contain an evaluation of reality by the speaker which helps to convey ideas.)

Diệp Quang Ban (2005: 16) in his work Ngũ pháp tiếng Việt makes a sharp distinction between the notion of cú (clause) and that of câu (sentence). He figures out the following three features characterizing the sentence:

a. Định vị câu (câu đơn) ở bậc cao nhất của hệ thống ngữ pháp của một ngôn ngữ, tức là về ngữ pháp không có đơn vị nào lớn hơn câu. (A simple sentence is ranked as the highest level in grammatical system of a language; i.e. grammatically, no other grammatical units are higher than the sentence.) 
b. Câu có cấu tạo ngữ pháp là một khúc đoạn ngôn ngữ tập trung chung quanh một vị tố, tức là lấy vị tố làm trung tâm, không lấy hai thành phần chủ ngữ và vị ngữ làm cơ sở, để tránh lập lại cấu trúc của mệnh đề logic. Đây cũng chính là nói về cái tổ chức từ vựng - ngữ pháp của câu. Nhờ tổ chức từ vựng - ngữ pháp này mà một ý nghĩ, một nội dung sự việc và ý định của người nói được định hình, được kiến tạo nên. (A sentence has a grammatical structure; it is a syntagm centering around a verb, taking the verb, not the subject and the predicate as its centre to avoid the repetition of the subject-predicate structure in logic. This is the lexico-grammatical structure of the sentence. It is due to this lexico-grammatical organization that the speaker's idea or intention is formulated and constructed.)

c. Câu có mặt ý nghĩa là phần diễn đạt một sự thể. Nghĩa sự thể là cái được dùng để giải thích cho tổ chức từ vựng-ngữ pháp của câu. (A sentence has a meaning expressing a state of affair. This kind of meaning is used for interpreting the lexicogrammatical organization of the sentence)

It can be seen that these above definitions reflect at least three features of the sentence: (i) a sentence is a linguistic unit which belongs to Parole in the sense of Saussure; (ii) it has a grammatical structure and a terminal intonation; and (iii) it has a meaning and its function is to express an idea, a complete thought or a message. Since sentences are examined form various perpectives, it is not surprising that the criteria and interpretations of them vary. However, it is worthy noting that the definitions and interpretations of sentences in this post-structural period saw a shift from "state" to "dynamic" aspect, from "structure" to "semantics" and "pragmatics".

I have provided a brief discussion on the pre-structuralist and structuralist approaches to Vietnamese syntax. Our study reveals that the structural approach has come into existence over a span of 155 years and greatly influenced the study of Vietnamese syntax. Clearly, southern linguists were influenced by American descriptivist/ structuralist (particularly the grammatical models of Emeneau and Thompson) while Northern linguists have heavily relied on the framework of European structuralism. However, no matter how different these approaches are, they share the same syntactic pattern, analyzing the simple sentence into Subject-Predicate. It was not until 1980s that semantics and pragmatics became a major concern for Vietnamese grammarians. And it is to the functional approaches to Vietnamese simple clauses that I now turn.

\section{Functional approaches to the analysis of the Vietnamese simple clause}

Although the study of Vietnamese grammar from functional approach began much later as compared with structural approach, functional approach has attracted a lot of intention of scholars and linguists. Our study points out that Dik's functional grammar and Halliday' systemic functional grammar are two major contemporary functional linguistic theories to clause description.

\subsection{Dik's functional grammar}

We have had a detailed discussion on structural approach with its strengths and shortcomings. This section is devoted to functional analysis of Vietnamese simple clauses. In 1991, Cao Xuân Hạo published a grammar book entitled Tiếng Việt: So thảo Ngũ pháp Chúc năng (An Outline of Vietnamese Functional Grammar). This book, according to several Vietnamese grammarians, makes a turning point in the study of Vietnamese grammar, shifting the analysis of the clause from traditional approach to what is referred to as functional approach by Dik (1989)'s Functional Grammar and states that Dik's grammar is functional because the conceptual framework on which it is based is a functional one rather than a formal one. From this point of view, grammar becomes a study of how 
meanings are built up through the wording in Vietnamese. However, Cao Xuân Hạo just reviews Dik's account of the functions of language instead of employing it to analyze and interpret Vietnamese grammar.

Dik's functional grammar is representative of the functional paradigm in linguistic theory in which language performs the function of communication for human beings. Dik (1997: 27) puts an emphasis on the functions of language and states that "functions are also needed because functions and categories do not stand in one-to-one relation to each other. The same category may occur in different functions and the same function may apply to constituents with different constituents with different categorical properties." Dik (1997: 49) states that "any natural language text can be divided into clauses and and extra-clausal constituents. By 'clauses' I mean the main and subordinate clauses of traditional grammar." Extra-clausal constituents are constituents which neither clauses nor part of clauses. For example

(9) Well, John, I believe that your time is up.

(Dik, 1997: 49)

"Well" (interpreted as "Inititator") and "John" (labeled as "Address" or "Vocative") are extra-clausal constituents while "I believe that your time is up" is the main clause where "your time is up" is the subordinate clause. Clauses in Dik's functional grammar are treated and analyzed in terms of syntactic, semantic and pragmatic functions.

Syntactic functions: Subject and Object

Semantic functions: Agent, Goal, Recipient, Beneficiary, Instrument, Location, Time

Pragmatic functions: Theme, Topic, Focus, Non-focus

Dik's account of syntactic functions which involves with Subject-Object structure to a certain extent bears some similarities to structural approach to the analysis of clause syntax. Therefore, syntactic functions are not discussed in the next section. Instead, attention will be paid to semantic and pragmatic functions.

\section{Semantic functions}

Vietnamese clauses are interpreted in terms of semantic functions with entities, phenomena and processes. Nevertheless, criteria used for assigning and labeling entities, phenomena and processes with their semantic functions are complex. This is what Nguyễn Văn Hiệp (2012: 47) has to say: "Trong việc phân định và trừu xuất vai nghĩa như vậy, cần một nguyên tắc mang tính phương pháp luận" (in assigning such semantic functions to entities, phenomena and processes, we need a methodological approach). In their semantic functions, both Halliday (1994) and Dik (1989) take processes ("verbs" in traditional grammar) as the core role of clauses and the other participants are labeled respectively. However, Halliday classifies processes into six categories namely material, mental, relational, behavioral, verbal, and existential while Dik (1989) divides them into two main types of States of Affairs namely Event (subtypes: action= activity or accomplishment and process $=$ dynamism or change $)$, Situation (subtypes: postion and state) with five parameters \pm dynamic $[ \pm$ dyn], \pm telic $[ \pm$ tel] \pm [mon] momentaneous, \pm [con] control and \pm [exp] experience. Diệp Quang Ban analyzes and labels Vietnamese processes as action and state with parameter $[ \pm$ dyn]. The author states that "Sự việc vốn diễn biến hoặc tồn tại dưới những dạng nhất định, nhờ đó có thể phân biệt được sự việc động, sự việc tĩnh (không động). Tính động, tính tĩnh là thể trạng của sự việc (States of Affairs, viết tắt: SoA) gọi tắt là sự thể." (Processes might be dynamic or static. The dynamic or static state of processes can be coded as States of Affairs (SoA)). Let us consider Diệp Quang Ban's interpretation of the clause in light of Dik's semantic functions. 
(10)

\begin{tabular}{|c|c|c|}
\hline $\begin{array}{c}\text { Cậu bé } \\
\text { The little boy }\end{array}$ & $\begin{array}{c}\text { vẽ } \\
\text { paint }\end{array}$ & $\begin{array}{c}\text { con cá. } \\
\text { fish }\end{array}$ \\
\hline Actor & Action - $[+$ dyn $]$ & Factive \\
\hline
\end{tabular}

'The little boy paints the fish.'

(Diệp Quang Ban, 2013:34)

(11)

\begin{tabular}{|c|c|}
\hline $\begin{array}{c}\text { Con mèo } \\
\text { Cat }\end{array}$ & $\begin{array}{c}\text { ốm. } \\
\text { sick }\end{array}$ \\
\hline Sensor & State $-[-$ dyn $]$ \\
\hline
\end{tabular}

'The cat is sick.'

(Diệp Quang Ban, 2013:34)

According to Diệp Quang Ban (2013: 29predicates in a clause in terms of semantic 34 ), there are thirteen kinds of semantic functions of subjects and three types of functions in Vietnamese shown in the following tables.

Table 1. Thirteen kinds of semantic functions of subjects in the Vietnamese clause

\begin{tabular}{|c|c|c|}
\hline No & Semantic functions of subjects & Examples \\
\hline 1 & Động thể (actor) & $\begin{array}{c}\text { Chiếc lá rơi nhanh. } \\
\text { (The leave is falling down quickly.) }\end{array}$ \\
\hline 2 & Tĩnh thể (inactive agent) & $\begin{array}{l}\text { Búc tranh treo ở trên tường. } \\
\text { (The painting was hung on the wall.) }\end{array}$ \\
\hline 3 & Cảm thể (sensor) & $\begin{array}{c}\text { Câuu bé nghĩ về bài tập toán. } \\
\text { (The little boy thinks of his math homework.) }\end{array}$ \\
\hline 4 & Phát ngôn thể (sayer) & $\begin{array}{l}\text { Cạu bé hỏi đường ra bến xe. } \\
\text { (He asks the way to the station.) }\end{array}$ \\
\hline 5 & Đích thể (goal) & $\begin{array}{l}\text { Tị được khen. } \\
\text { (Ti was praised.) }\end{array}$ \\
\hline 6 & Recipient (tiếp thể) & $\begin{array}{c}\text { Thuyền đã được lắp máy mới. } \\
\text { (The ship was equipped with new machines.) }\end{array}$ \\
\hline 7 & Đắc lợi thể (beneficiary) & $\begin{array}{c}\text { Em bé được bạn chép bài hộ. } \\
\text { (The child has her class notes written by her friend.) }\end{array}$ \\
\hline 8 & Bị hại thể (patient) & $\begin{array}{l}\text { Ngu dân bị bão đánh đắm thuyền. } \\
\text { (The fisherman's boat was hit and sunk by the storm.) }\end{array}$ \\
\hline 9 & Đích đến (target) & $\begin{array}{c}\text { Cầu bị bom ném trúng. } \\
\text { (The bridge was hit by bombs.) }\end{array}$ \\
\hline 10 & Vị trí (location) & $\begin{array}{l}\text { Thùng đầy nước. } \\
\text { (The bucket is full of water) }\end{array}$ \\
\hline 11 & Phương tiện (instrument) & $\begin{array}{l}\text { Chì khóa này mở phòng số } 4 . \\
\text { (This key opens room 4.) }\end{array}$ \\
\hline 12 & Nguyên nhân (cause) & $\begin{array}{l}\text { Bão làm đổ cây. } \\
\text { (The storm makes the trees fall down.) }\end{array}$ \\
\hline 13 & Chủ thể quan hệ (relational agent) & $\begin{array}{l}\text { Ông này là thợ mộc. } \\
\text { (This man is a carpenter.) }\end{array}$ \\
\hline
\end{tabular}

Table 2. Three types of semantic functions of predicates in the Vietnamese clause

\begin{tabular}{|c|c|c|}
\hline No & Semantic functions of predicates & Examples \\
\hline 1 & Sự thể động (dynamic state) & $\begin{array}{c}\text { Cậu bé dứng dây. } \\
\text { (The boy stands up.) }\end{array}$ \\
\hline 2 & Sự thể tĩnh (inactive state) & $\begin{array}{c}\text { Ruộng ngập nước } \\
\text { (The paddy-field is flooded with water.) }\end{array}$ \\
\hline 3 & Quan hệ trừu tượng (relation) & $\begin{array}{c}\text { Ông này là giám đốc } \\
\text { (This man is a director) } \\
\text { Ngôi nhà ây của Ông X } \\
\text { (That house belongs to Mr.X) }\end{array}$ \\
\hline
\end{tabular}


As for the semantic functions of predicates, although Diệp Quang Ban (2013)'s interpretation is far simpler than Dik's, readers would still be confused about a wide variety of semantic functions of subjects and might wonder why Diệp Quang Ban offers so many semantic functions. We believe that a lot of Vietnamese learners, scholars have many troubles interpreting and analyzing Vietnamese clauses. The more detailed he suggests, the more complex his interpretation is.

\section{Pragmatic functions}

Subject-Predicate description is by no means comprehensive when clauses are examined and interpreted from functional perspective. Theme-Rheme interpretation is adopted as an alternative although ThemeRheme studies are controversial with a variety of terms, concepts and frameworks to analyze Vietnamese clauses. In many cases in Vietnamese, the first initial elements are not the psychological entities (actors, sayers, sensors, and behavers) to be labeled as subjects and do not correspond to the predicates (subject-predicate structure). These first elements are interpreted as "Khởi ngữ" (thematic elements) by Nguyễn Kim Thản (1964) and as "chủ đề" (topical themes) to have advantage over subject-predicate analysis in case first elements of clauses are not real subjects and do not correspond to predicates. Obviously, Theme-Rheme analysis might overcome shortcomings of subject-predicate analysis.

To some extent, Dik's pragmatic function assignment is similar to Halliday's textual function but not equivalent. Dik (1989:129) states that notions such as Topic vs Comment, Theme vs Rheme, Given vs New, Focus vs Presupposition can be interpreted as pragmatic functions. Dik (1989:130) sees that Theme does not fall into predication but connects to it in virtue of its pragmatic character. In contrast, Topic and Focus are considered as constituents of the predication proper:

A constituent with Topic function presents the entity about which the predication predicates something in a given setting. A constituent with Focus function presents the relatively most important or salient information with respect to the pragmatic information of the Speaker and the Addressee.

Theme-Topic-Focus structure is utilized on the account of Dik's functional grammar while Theme-Rheme structure is adopted in Halliday's systemic functional grammar. For example:

(12)

\begin{tabular}{|c|c|c|}
\hline $\begin{array}{c}\text { Thất vọng, } \\
\text { disappointed }\end{array}$ & $\begin{array}{c}\text { chị Dậu } \\
\text { Ms. Dậu }\end{array}$ & $\begin{array}{c}\text { rũ người ngồi im. } \\
\text { tired people sit quiet. }\end{array}$ \\
\hline Theme & Topic & Focus \\
\hline "Being disappointed, Ms. Dậu was tired out and sat quietly.' (Ngô Tất Tố, 1937)
\end{tabular}

by Trương Văn Chình and Nguyễn Hiến Lê (1963) and Nguyễn Văn Hiệp (2012). In addition, Halliday's conception of theme as initial elements is shared by many Vietnamese linguists such as Cao Xuân Hạo (1991), Đào Thanh Lan (2002), Diệp Quang Ban (2013), Nguyễn Văn Hiệp (2012), Trần Kim Phượng (2010), Nguyễn Hồng Cổn (2009) and others. It is noted that Theme-Rheme analysis seems
Dik (1989:31) states that "Theme can not be regarded as being part of a predication". In (12) "thất vọng" - ECC (extra-clausal constituent) may fulfill the function of Theme and "chị Dậu" and "rũ người ngồi im" are labled as "Topic" and "Focus" respectively. Our study reveals that Dik's Theme-TopicFocus cannot work when interpreting Vietnamese clauses. Vietnamese scholars, linguists and grammarians show their more 
interest in Halliday's Theme-Rheme structure. (See 3.2)

\subsection{Halliday's Systemic Functional Grammar}

Based on three metafunctions or three lines of meanings suggested Halliday (1994); Halliday and Matthiessen (2004, 2014), Vietnamese simple clauses are analyzed in terms of three aspects of meanings: the first is ideational meanings realized in transitivity system: Participant-Process-Circumstance, Interpersonal meaning realized in Mood, Modality and Textual with Theme and Rheme, Given and New. Hoàng Văn Vân (2002, 2012) adopts Halliday's functional grammar's framework to describe the experiential grammar of Vietnamese clauses and Thái Minh Đức (1998) attempts to analyze the Vietnamese clause in terms of all three lines of meanings as developed by Halliday.

Experiential metafunction

Vietnamese contemporary functional approaches to clause analysis are almost influenced by either Halliday's or Dik's approach. Let us illustrate how Vietnamese simple clauses are analyzed in terms of experiential (ideational) meaning first in light of Halliday's functional grammar.

(13)

\begin{tabular}{|c|c|c|c|}
\hline $\begin{array}{c}\text { Hôm sau } \\
\text { The following day }\end{array}$ & $\begin{array}{c}\text { lão Hạc } \\
\text { Elderly Hac }\end{array}$ & $\begin{array}{c}\text { sang } \\
\text { come }\end{array}$ & $\begin{array}{c}\text { nhà tôi. } \\
\text { my house }\end{array}$ \\
\hline Circumstance & Actor & Process: material & Scope: entity \\
\hline
\end{tabular}

'The following day Mr. Hac drops by my house.'

(Nam Cao, 1965)

(14)

\begin{tabular}{|c|c|c|}
\hline $\begin{array}{c}\text { Chí Phèo } \\
\text { Chi Pheo }\end{array}$ & $\begin{array}{c}\text { không là } \\
\text { not is }\end{array}$ & $\begin{array}{c}\text { anh hùng. } \\
\text { hero }\end{array}$ \\
\hline Identified & Process: relational & Identifier \\
\hline
\end{tabular}

'Chi Pheo is not a hero.'

(Nam Cao, 1965)

(15)

\begin{tabular}{|c|c|c|}
\hline $\begin{array}{c}\text { Lão } \\
\text { Elderly }\end{array}$ & $\begin{array}{c}\text { kể } \\
\text { talk }\end{array}$ & $\begin{array}{l}\text { nhỏ nhẹ và dài dòng thật. } \\
\text { soft and lengthy real }\end{array}$ \\
\hline Sayer & Process: Verbal & Circumstance - manner \\
\hline
\end{tabular}

'He says in a soft and lengthy manner.'

(Nam Cao, 1965)

(16)

\begin{tabular}{|c|c|c|c|}
\hline $\begin{array}{c}\text { Tôi } \\
\text { I }\end{array}$ & $\begin{array}{l}\text { thấy } \\
\text { see }\end{array}$ & $\begin{array}{l}\text { vẻ buồn } \\
\text { sadness }\end{array}$ & $\begin{array}{l}\text { trên khuôn mặt của bà } \\
\text { on face of her }\end{array}$ \\
\hline Senser & Process: mental & Phenomenon & Cir- location \\
\hline
\end{tabular}

'I recognize a deep sadness on her face.'

(Bùi Minh Toán, 2012: 40)

(17)

\begin{tabular}{|c|c|c|}
\hline $\begin{array}{c}\text { Thịnh } \\
\text { Thinh }\end{array}$ & $\begin{array}{c}\text { cười } \\
\text { laugh }\end{array}$ & $\begin{array}{c}\text { khanh khách. } \\
\text { peals of laughter }\end{array}$ \\
\hline Behaver & Process: behavioral & Circumstance-manner \\
\hline
\end{tabular}

'Thinh burst into peals of laughter.'

(Tô Hoài, 1941)

(18)

\begin{tabular}{|c|c|c|}
\hline $\begin{array}{c}\text { Ngày xưa } \\
\text { Once upon a time }\end{array}$ & $\begin{array}{c}\text { có } \\
\text { have }\end{array}$ & $\begin{array}{c}\text { anh học trò nghèo. } \\
\text { student poor }\end{array}$ \\
\hline Circumstance - time & Process: existential & Existent: entity \\
\hline
\end{tabular}

'Once upon a time, there was a poor male student.'

(Tô Hoài, 1941) 
According to Hoàng Văn Vân(2002,2012), in terms of experiential meaning, there are also six kinds of clauses in Vietnamese, namely material, mental, relational, behavioral, verbal, and existential. Participants in general or Actor, Senser, Behaver, Sayer in particular are realized by either pronouns or noun groups while Processes are realized by verbal groups or adjective groups.

\section{Interpersonal metafunction or modality}

In this section, Vietnamese simple clauses are examined in terms of Modality and Mood. It seems possible to recognize a simple but very basic aspect in terms of modality, one which considers clauses as utterances and examines them in light of social role function. An utterance often has an element of content and should be seen as exchange of information in a particular context. Many Vietnamese linguists and teachers have had increasing awareness of Modality in Vietnamese but with different viewpoints. However, there is a general consensus among Vietnamese linguists about the Mood types namely, affirmatives (declaratives); imperative; interrogatives and exclamatives. Let us consider the following examples.

(19) Từ sáng đến giờ, chị chỉ long đong chạy đi chạy về. (affirmatives)

'She spent all morning running errands.'

(Ngô Tất Tố, 1937)

(20) Bây giờ chị Týđâu rồi? (interrogatives) (Ngô Tất Tố, 1937)

'Where is Ms. Ty now?'
(21)
Ông không
thiếu tiền! (exclamatives)

(Nam Cao, 1965)

'Listen! I am not short of money!'

(22) Con hãy nín đi, cho em nó ngủ. (imperatives)

(Ngô Tất Tố, 1937)

'Please stop crying, let your baby sister sleep'
It should be noted that besides tone, Vietnamese imperatives are often accompanied by mood adjuncts "hãy", "đùng”, "thôi” and “đi” (Diệp Quang Ban, 2013: 119) as in:

(23) Anh đì̀ng đi vội! (Don’t leave in a hurry!)

(24) Anh hãy ngồi xuống đây đã! (Please take a seat, here!)

(25) Ta đi thôi! (Let's go!)

(26) Cậu nói đi! (You should speak out!)

According to Diệp Quang Ban (2013:120), In (24) (25) and (26), these adjuncts "hãy", "thô $i$ " and " $i i "$ are considered as "functional/ empty words" rather than lexical ones. English exclamatives have the WH-element as what or how, in nominal or adverbial group (What a darling you are! Or how secretive you are!) (Halliday, 2004: 137), while Vietnamese exclamatives go with mood adjuncts like "ôi; $\hat{o}$ hay, ôi chao, lạ, thật, quá, ghê, thế, duoòng nào, biết mấy, sao mà, chết đi được and the others" and rising tones. (Diệp Quang Ban, 2013:120).

Unlike English, Vietnamese is monosyllabic and words do not change their forms with prefixes or suffixes. Bùi Minh Toán (2012:68) shows that Modality in Vietnamese is expressed by rising-falling tone and many other functional elements shown in Table 3. 
Table 3. Functional elements and words serving their functions

\begin{tabular}{|c|c|c|}
\hline No & Functional elements & Examples \\
\hline 1 & $\begin{array}{c}\text { Modal particles } \\
\text { (Temporal operators) }\end{array}$ & $\begin{array}{c}\text { đã, đang, sẽ, vừa, từng, mới, không, chưa, chẳng, hãy, đừng, chớ, đi, } \\
\text { nào, chợt, etc. }\end{array}$ \\
\hline 2 & Modal verbs & muốn, toan, định, dám, cố, được, bị, phạt, nên, cần, etc. \\
\hline 3 & Interrogative adjuncts & ai, gì, nào, sao, đâu, thế nào, có...không, đã....chưa \\
\hline 4 & $\begin{array}{c}\text { Modal particles at the } \\
\text { end of the clauses }\end{array}$ & à, ư, nhỉ, nhé, thôi, chứ, đi, mất, thật, nghe, xem, đây, đấy \\
\hline 5 & Exclamatives & ôi, chao ôi, ái chà, eo ôi, ủa, trời ơi, hỡi ơi... \\
\hline 6 & Vocatives & Bà con ơi!, Ông giáo à! \\
\hline 7 & Modal expressions & $\begin{array}{c}\text { nói gì thì nói, đằng thằng ra, lẽ ra, nói trộm bóng vía, thảo nào, ngó } \\
\text { chừng hóa ngờ, may ra, chằng may, tiếc là, quả nhiên là, xem ch có lẽ, phiền một nỗi, làng nước ơi!.. }\end{array}$ \\
\hline 8 & Comment adjuncts & $\begin{array}{c}\text { tôi nghĩ..., tôi cho rằng..., tôi e rằng,... tôi sợ rằng ..., may là, đáng } \\
\text { buồn là, mừng là }\end{array}$ \\
\hline 9 & Conjunctive adjuncts & nếu...thì..., giả sử ... thì..., giá mà ...thì...., có....mới... \\
\hline
\end{tabular}

For examples:

(27) Thì ra lão đang nghĩ đến thằng con lão. (temporal operators)

(Nam Cao, 1965)

'Then he is thinking of his son.'

(28)Tôi sẽ chí giữ gìn cho lão. (temporal operators)

(Nam Cao, 1965)

'I will try my best to keep it safe for him'

(29) Hắn nhặt một hòn gạch toan đập đầu. (modal verbs )

(Nam Cao, 1965)

'He picks up a piece of brick, intending to hit his head.'

(30) - Chí Phèo đấy hở ? (interrogative adjuncts)

(Nam Cao, 1965)

'Is that you there, Chi Pheo?'

(31) - Phúc đời nhà mày, con nhé. (vocatives)

(Nam Cao, 1965)

'Boy! You are very lucky.'

(32) Có lẽ tôi bán con chó đấy, ông giáo a! (vocatives)

(Nam Cao, 1965)

'I will probably sell this dog, Sir!'
(33) - Mừng à? Vẫy đuôi à? (modal particles at the end of the clauses)

(Nam Cao, 1965)

'Happy? Wag your tail?'

(34) Hinh nhu anh muốn nói thêm một câu gì đó (comment adjuncts)

(Vũ Trọng Phụng, 1938)

'It seems that he wants to say something else.'

(35) Ối làng nước ôi! Bố con thằng Bá Kiến nó đâm chết tôi! (modal expressions)

(Nam Cao, 1965)

'Oh my god! Ba Kien and his son have stabbed me!'

(36) $\hat{A y}$ thế mà tôi cũng bán! (modal expressions)

'Yet I also sell it!'

(37) Hỡi ơi lão Hạc! Thì ra đến lúc cùng lão cũng có thể làm liều như ai hết. (exclamatives)

(Nam Cao, 1965)

'Oh dear! My best friend! When you were driven into a corner, you dared to kill yourself.'

(38) Còn cô Tuyết, người yêu của Xuân Tóc Đỏ cũng phải cảm động mà liếc ... (conjunctive adjuncts)

(Vũ Trọng Phụng, 1938) 
'And Ms. Tuyet, Red haired Xuan's lover, was touched and stared.'

It is safe to say that modality should be interpreted in contexts where speakers and listeners play crucial roles in exchanging information. In Vietnamese, a modality is expressed via either verbal channel or nonverbal one. The former is concerned with words and tones while the latter is related to gestures, facial expressions and others. In fact, modality particles at the end of the clauses cause several problems to both Vietnamese and foreign learners to recognize and interpret them.

Three major concerns over Vietnamese modality will be discussed in this section: One is closely related to modal particles (temporal operators) and modal verbs, another is associated with modality particles at the end of the clauses, and the other is relevant to analyzing clauses in terms of mood and residue suggested by Diệp Quang Ban (2013). Firstly we will examine modal particles (temporal operators) and modal verbs as well as show some marked differences between them (see Nguyễn Văn Hiệp, 2012). Consider the following examples:

(39) Hắn vùua đi vừa chửi. (modal partices) (Nam Cao, 1965)

'He went and cursed.'

(40) Lão đùng lo gì cho cái vườn của lão. (modal particles)

(Nam Cao, 1965)

You shouldn't worry too much about your yard.'

(41) Lão Hạc không lo được. (modal particles)

(Nam Cao, 1965)

'Old Mr. Hac can't handle that'

(42) Cụ chỉ muốn cho tất cả những thằng trai trẻ đi tù. (modal verbs)

(Nam Cao, 1965)

'He just wants all young guys to be put into prison.'
(43) Chúng mình chả nên nuôi một thằng dế ốm. (modal verbs)

(Tô Hoài, 1941)

'We shouldn't feed a weak cricket.'

"Vừa...vừa" (both....and), “đừng" (don't), "không" (no) in (39); (40) and (41) are examples of modal particles and they are distinguished from modal verbs "muốn" (want) and "nên" (should) in (42) and (43). In Vietnamese, modal particles outnumber modal verbs (Nguyễn Văn Hiệp, 2012: 141) and it is helpful to list them. To a certain extent, both modal particles and modal verbs are within predicators.

Secondly, modality particles at the end of the clauses play crucial roles in terms of modality. In Vietnamese, modality is expressed by modal particles such as à, chí, nhỉ, nhé, hả, chứ gì, được không, đúng không, được chư or by using couples of modal particles such as "có...không”, "đã...chura”, " có phải... không”, "có...chura”. General questions in Vietnamese do not use any intonation as well as any operators and inversions. Let us consider the following examples:

(44) Thắp đèn lên chị Liên nhé?

(Thạch Lam, 1938)

'Let's light up the candle.'

(45) Phúc đời nhà mày, con nhé.

(Nam Cao, 1957)

'Great luck smiles on you.'

The question is: why do they differ in terms of modality? Here it is vital to take into account the modality functions of modal particles. In Vietnamese, modal particles are sometimes either "functional/empty" words or "lexical/ full" words based on different patterns of clauses as well as particular contexts. We need to draw a distinction between "nhé" in (44) and (45). This is the distinction between the purpose of the speakers as well as modality (interpersonal metafunction). The former is an example of question in Vietnamese whilst the latter is a statement. Likewise, there is a difference in terms of modality as in: 
(46) Sao hôm nay chị dọn hàng muộn thế?

(Thạch Lam, 1938)

'Why are you open for business late today?'

(47) Mẹ còn bận làm gạo $\boldsymbol{c o r}^{\prime}$ mà .

(Thạch Lam, 1938)

'Our mum is still busy processing rice.'

It can be seen that both Diệp Quang Ban's and Nguyễn Văn Hiệp's suggested analysis and models leave many unsolved problems like troubles in analyzing clauses in the view of interpersonal meaning and their interpretations are still controversial among Vietnamese linguists and scholars.

\section{Textual metafunction (theme-rheme analysis)}

Theme-Rheme analysis is not an exception in this respect in Vietnam. Textual metafunction looks inwards to the text itself and sees clause as message (Halliday \& Matthiessen, 2014).

Textual metafunction (Theme-Rheme) is a new framework of analyzing clauses in modern Vietnamese grammar which helps us deal with some difficulties in interpreting and analyzing a clause that traditional grammar cannot tackle. Drawing on Halliday (1994), Diệp Quang Ban (2013) sets out an interpretation of the clause in the function as

(51)

\begin{tabular}{|c|c|c|}
\hline $\begin{array}{c}\text { Tiếng vậy, } \\
\text { Rumour has it }\end{array}$ & $\begin{array}{c}\text { làm tổng lý } \\
\text { being local authority }\end{array}$ & $\begin{array}{c}\text { không phải việc dễ } \\
\text { not easy }\end{array}$ \\
\hline Interpersonal theme & Topical theme & Rheme \\
\hline \multicolumn{2}{|c|}{ Theme }
\end{tabular}

'Being a local authority is not as easy as people think.'

(Nam Cao, 1965)

(52)

\begin{tabular}{|c|c|c|}
\hline $\begin{array}{c}\text { Nhưng kìa } \\
\text { But }\end{array}$ & $\begin{array}{c}\text { cụ ông } \\
\text { the old man }\end{array}$ & $\begin{array}{c}\text { đã về } \\
\text { came }\end{array}$ \\
\cline { 1 - 2 } textual theme & Topical theme & Rheme \\
\hline \multicolumn{2}{|c|}{ Theme } & Ram Cao, 1965) \\
\hline \multicolumn{2}{|c|}{}
\end{tabular}

'But the old man came home'

(Nam Cao, 1965)

(53)

\begin{tabular}{|c|c|c|c|}
\hline $\begin{array}{c}\text { Có lẽ } \\
\text { Maybe }\end{array}$ & $\begin{array}{c}\text { tôi } \\
\text { I }\end{array}$ & $\begin{array}{c}\text { bán con chó đấy, } \\
\text { sell the dog }\end{array}$ & $\begin{array}{c}\text { ông giáo ạ. } \\
\text { teacher }\end{array}$ \\
\hline Interpersonal theme & Topical theme & \multicolumn{2}{|c|}{ Rheme } \\
\hline \multicolumn{2}{|c|}{ Theme }
\end{tabular}

'Sir, maybe I'll sell my dog.'

(Nam Cao, 1965) 
According to Diệp Quang Ban (2013), like English, the most common type of topical theme in a Vietnamese clause is a nominal group functioning as a Subject labeled as unmarked theme. Nevertheless, in many cases, there are some adverbial groups for ấy" (at that time) as "khung đề" (thematic frame) and "không đợi anh ấy trả lời" (not waiting for his reply) as "xác minh ngữ" (identification expression) whilst Diệp Quang Ban sees them as marked themes, and subjects "Bá Kiến" and "cô" as parts of Rheme. It s

(54)

\begin{tabular}{|c|c|}
\hline $\begin{array}{c}\text { Hồi ấy, } \\
\text { At that time }\end{array}$ & $\begin{array}{c}\text { Bá Kiến mới ra làm lý trưởng. } \\
\text { Ba Kien just be a ly-truong }\end{array}$ \\
\hline Marked theme & Rheme \\
\hline
\end{tabular}

'At that time, Ba Kien was a newly appointed local authority.' (Nam Cao, 1965)

(55)

\begin{tabular}{|c|c|}
\hline $\begin{array}{l}\text { Không đợi anh trả lời } \\
\text { No wait he answer }\end{array}$ & $\begin{array}{l}\text { cô cất giọng hát } \\
\text { she voice sing }\end{array}$ \\
\hline Marked theme & Rheme \\
\hline
\end{tabular}

'Not waiting for his reply, she starts to sing.'

(Trần Kim Phượng, 2010: 2)

example "hôm qua" (yesterday), "ỏ ngoài sân" (in the yard), "với món tiền này" (with this amount of money) and others functioning as adjuncts interpreted as marked theme. In a simplex clause, there is only one topical theme. Therefore, whenever an adjunct is interpreted as marked theme, the real subject corresponding to the predicate must be labeled as rheme. It is illustrated in the following examples.

$\left(54^{\prime}\right)$ obvious from what we discussed that ThemeRheme analysis is debatable in Vietnamese with different terms, frameworks and principles to segment clauses in terms of Theme and Rheme and to a certain extent, this analysis is adapted and re-defined. The most common principle to divide theme and rheme in clauses shared by most Vietnamese linguists is based on words such as "thì", "mà", "là" (be) as they are employed to mark the

\begin{tabular}{|c|c|c|}
\hline Hồi ấy, & Bá Kiến \\
At that time & Ba Kien & $\begin{array}{c}\text { mới ra làm lý trưởng. } \\
\text { just be a ly-truong }\end{array}$ \\
\hline Thematic frame & Topical theme & rheme \\
\hline
\end{tabular}

'At that time, Ba Kien was a newly appointed local authority.'

(55')

\begin{tabular}{|c|c|c|}
\hline $\begin{array}{c}\text { Không đợi anh trả lời } \\
\text { No wait he answer }\end{array}$ & $\begin{array}{c}\text { cô } \\
\text { she }\end{array}$ & $\begin{array}{c}\text { cất giọng hát } \\
\text { voice sing }\end{array}$ \\
\hline Identification expression & Topical theme & rheme \\
\hline
\end{tabular}

'Not waiting for his reply, she starts to sing.'

There is an alternative Theme-Rheme analysis of these two examples. Trần Kim Phượng (2010) suggests another interpretation of marked theme as well as Rheme as shown in the following:

Trần Kim Phượng (2010) considers "hồi boundary of Theme and Rheme (Cao Xuân Hạo, 2006) as in:

Last but not least, the element which is typically chosen as Theme in Vietnamese clauses depends on the choice of mood: declarative, interrogative, or imperative. 
(56)

\begin{tabular}{|c|c|c|}
\hline $\begin{array}{c}\text { Làm quái gì } \\
\text { What the hell! }\end{array}$ & $\begin{array}{c}\text { một con chó } \\
\mathrm{a} \text { dog }\end{array}$ & $\begin{array}{c}\text { mà lão có vẻ băn khoăn quá thế. } \\
\text { but he seem concerned too Modality. }\end{array}$ \\
\hline Interpersonal theme & Topical theme & Rheme \\
\hline \multicolumn{2}{|c|}{ Theme }
\end{tabular}

'What the hell! It is just a dog but he seems to be too concerned about it.' (Nam Cao, 1965) (57)

\begin{tabular}{|c|c|}
\hline $\begin{array}{c}\text { Ở tù } \quad \text { thì hắn coi } \\
\text { In prison THI he consider }\end{array}$ & là thường \\
LA normal
\end{tabular}

'It doesn't matter if he is in prison.'

(Nam Cao, 1965)

(1) Theme in declarative clauses. In a Vietnamese declarative clause, theme is either unmarked or marked. Unmarked theme refers to subject corresponding to predicate while marked theme is related to adjuncts (adverbial groups). Examples:

(58)

\begin{tabular}{|c|c|}
\hline $\begin{array}{c}\text { Tôi } \\
\text { I }\end{array}$ & \multicolumn{2}{|c|}{$\begin{array}{c}\text { cũng không buồn. } \\
\text { too not sad }\end{array}$} \\
\hline Unmarked theme & Rheme \\
\hline
\end{tabular}

'I am not sad either.'

(Tô Hoài, 1941)

(59)

\begin{tabular}{|c|c|}
\hline Từ đây, & tôi bắt đầu vào cuộc đời của tôi \\
\hline From now on & I start into life \\
\hline Marked theme & Rheme \\
\hline
\end{tabular}

'From now on, I start my life.'

(Tô Hoài, 1941)

(2) Theme in interrogative clauses. Like English, in Vietnamese there are two main types of questions: one where what the speaker wants to know such as "rồi, dạ rồi, có, phải" (yes) or "chưa xong, chưa rồi, không, dạ không” (no), etc., e.g. "Họ về chưa" (have they left yet?) "Bạn có mệt không" (Are you tired?); the other where what the speaker wants to know is the identity of some elements in the content, e.g. "Anh tìm cái gì?" (What are you looking for?) "Ai gõ cửa?" (Who is knocking at the door?) "Điều gì khiến bạn vui?" (What makes you happy?). It is noticeable that in Vietnamese WHinterrogatives, WH-elements that express the nature of the missing information: who, what, where, when, etc., can stand either at the beginning or at the the end of the clauses. Particularly, WH-elements functioning as subjects always precede predicate and they are labeled as theme whereas they are interpreted as Rheme when they stand at the end of the clause and function as object. Consider the following examples.

(60)

\begin{tabular}{|c|c|}
\hline $\begin{array}{c}\text { Chị Cốc béo xù } \\
\text { Ms. Coc fat }\end{array}$ & $\begin{array}{c}\text { đứng trước cửa nhà } \\
\text { ta ây hả ? } \\
\text { stand front door house } \\
\text { I Modality? }\end{array}$ \\
\hline Theme & Rheme \\
\hline
\end{tabular}

'The Fatty Ms.Coc standing in front of the door of my cave?'

(Tô Hoài, 1941)

(61)

\begin{tabular}{|c|c|}
\hline $\begin{array}{c}\text { Anh Chí } \\
\text { Mr. Chi }\end{array}$ & $\begin{array}{c}\text { đi đâu đấy? } \\
\text { go where }\end{array}$ \\
\hline Theme & Rheme \\
\hline
\end{tabular}

'Where are you going, Brother Chi?'

(Nam Cao, 1965)

(62)

\begin{tabular}{|c|c|}
\hline $\begin{array}{c}\text { Đứa nào } \\
\text { Who }\end{array}$ & \multicolumn{2}{|c|}{ cạnh khoé gì tao thế ? } \\
mock & what me THE \\
\hline Theme & Rheme \\
\hline
\end{tabular}

'Who is mocking at me?'

(Tô Hoài, 1941)

(3) Themes in imperative. Imperative expressions like “đi”, 'hãy” “đi thôi” (Let's) are often available in Vietnamese imperatives as in "hãy đi tìm Tị đi!" (look for Ti please!) or “đi đi thôi!” (Let's go!) and they are interpreted in terms of Theme-Rheme as follows. 
(63)

\begin{tabular}{|c|c|}
\hline $\begin{array}{c}\text { Hãy đi tìm } \\
\text { Let look for }\end{array}$ & Tị đi! \\
\hline Theme & Rheme \\
\hline
\end{tabular}

'Let's look for Ti!'

(64)

\begin{tabular}{|c|c|}
\hline $\begin{array}{c}\text { Đi } \\
\text { Go }\end{array}$ & $\begin{array}{c}\text { Đi thôi! } \\
\text { Go Modality }\end{array}$ \\
\hline Theme & Rheme \\
\hline
\end{tabular}

'Go now'

(Diệp Quang Ban, 2013: 136)

As discussed above, there are two major contemporary approaches namely structural and functional to the analysis of Vietnamese simple clauses. Each of these approaches has its advantages and disadvantages. However, there is no general consensus among Vietnamese teachers and linguists about the frameworks and models to analyze Vietnamese simple clauses. As a matter of fact, approaches and frameworks vary according to the particular linguistic theory.

Our discussion reveals that although the strength of functional approach lies in its main tenets of communication, there are a considerable number of terms and some indeterminate cases (Nguyễn Thị Tú Trinh et al, 2016) to label the semantic roles of clausal elements in the area of functional grammar. It appears likely that a lack of self-consistency in critera results in the problematic of identification of the clausal elments and therefore leads to the debatable functional adequacy of the analysis. (Butler, 1990: 13, 1991:507).

\section{Conclusion}

In this paper we have focused on investigating major contemporary approaches to the analysis of Vietnamese simple clauses. Our study reveals that structural approach has has the longest histroy since it seems to have been introduced in Vietnamese schools since the invasion of the French. Despite its shortcomings, structural approach or traditional grammar with Subject-Predicate forms the backbone of linguistic study in general and clause analysis in particular. However, structrural approach with its main tenets of grammarian rules and disciplines, syntactic and structural description is no longer dominant. Not until the 1990s, Cao Xuân Hạo (1991) published his book marking the advent of the functional approach to the analysis of the Vietnamese clause "Tiếng Việt: Sơ thảo Ngữ pháp chức năng". The prominent feature of the functional approach is that it sees language as a means of communication but not a set of rules. This can help to shoot a lot of troubles in clause analysis which traditional grammar cannot. It can also be seen from my discussion that most major contemporary approaches to the analysis of the Vietnamese clause have had their foreign origins developed by eminent Western linguists and grammraians such as Saussure, Bloomfield, Dik, Halliday.

\section{References}

\section{Vietnamese}

Diệp Quang Ban. (1984). Bàn về vấn đề thành phần câu ứng dụng vào tiếng Việt. In trong Nhũng vấn đề ngũ pháp tiếng Việt (Lưu Vân Lăng chủ biên). Hà Nội: Nxb Khoa học Xã hội.

Diệp Quang Ban (2005). Ngũ pháp tiếng Việt. Hà Nội: Nxb Giáo dục Việt Nam.

Diệp Quang Ban (2013). Ngũ pháp chưc năng. Hà Nội: Nxb Giáo dục Việt Nam.

Trương Văn Chình \& Nguyễn Hiến Lê (1963). Khảo luận về ngũ pháp Việt Nam. Huế: Đại học Huế.

Nguyễn Hồng Cổn (2009). "Cấu trúc cú pháp tiếng Việt: Chủ -Vị hay Đề - Thuyết?”. Tạp chí Ngôn ngũ số 2.

Cao Xuân Hạo (1991). Tiếng Việt: So thảo ngũ pháp chức năng (Vietnamese: An Outline of Functional Grammar). Hà Nội: Nxb Khoa học Xã hội.

Nguyễn Văn Hiệp (2012). Cơ sở ngũ nghĩa phân tích cú pháp. Hà Nội: Nxb Giáo dục.

Phan Khôi (1955). Việt Ngũ nghiên cứu. Hà Nội: Nxb Văn nghệ.

Trần Trọng Kim, Bùi Kỷ \& Phạm Duy Khiêm (1940). Việt-nam văn-phạm. Tái bản lần thứ 8 . Sài Gòn: Tân Việt 1960.

Đào Thanh Lan (2002). Phân tích câu đơn tiếng Việt theo cấu trúc đề-thuyết. Hà Nội: Nxb Đại học Quốc gia. 
Hoàng Trọng Phiến (1980). Ngũ pháp tiếng Việt: Câu. Hà Nội: Nxb Đại học và Trung học Chuyên nghiệp.

Trần Kim Phượng (2010). Các phương pháp phân tích câu tiếng Việt. Tạp chí Ngôn ngũ số 3, 35-47.

Lê Xuân Thại (1995). Câu chủ vị trong tiếng Việt. Hà Nội: Nxb Khoa học Xã hội.

Nguyễn Kim Thản (1964). Nghiên cúu về ngũu pháp tiếng Việt, Tập 2. Hà Nội: Nxb Khoa học Xã hội.

Đào Minh Thư, Đào Thị Minh Ngọc, Nguyễn Mai Vân, Lê Kim Ngân, Lê Thanh Hương, Nguyễn Phương Thái and Đào Bá Lâm (2009). Tập quy tắc cú pháp tiếng Việt (Principles of Vietnamese Syntax). SP8.5 - Đề tài KH.01.01.05/06-10. Việt Nam.

Bùi Đức Tịnh (1952). Văn phạm Việt Nam. Sài Gòn: Phan Văn Tươi.

Bùi Minh Toán (2012). Câu trong hoạt động giao tiếp. Hà Nội: Nxb Giáo dục Việt Nam.

Hoàng Văn Vân (2002). Ngũ pháp kinh nghiệm của cú tiếng Việt: Mô tả theo quan điểm chức năng hệ thống (An Experiential Grammar of the Vietnamese Clause: A Systemic Functional Description). Hà Nội: Nxb Khoa học Xã hội.

\section{English}

Bloomfield, L. (1933). Language. New York: Henry Holt.

Butler, C. S. (1990). "Functional grammar and systemtic functional grammar". Working Papers in Function Grammar 39, 1-49.

Butler, C. S. (1991). "Standard of Edequacy in Functional grammar". Journal of Linguistics 49, 499-515.

Dik, S. C. (1989). The Theory of Functional Grammar. Part 1. Dordrecht and Providence: Foris.

Dik, S. C. (1997). The Theory of Functional Grammar. 2 parts. (Edited by Kees Hengeveld). Functional Grammar Series 20. Berlin: Mouton de Gruyter.

Emeneau, M.B. (1951). Studies in Vietnamese (Annamese) Grammar. Berkeley \& Los Angeles: University of California Press.

Halliday, M.A.K. (1994). An Introduction to Functional Grammar. London: Arnold.

Halliday, M.A.K. \& Matthiessen, C.M.I.M. (2004). An introduction to Functional Grammar. $3^{\text {rd }}$ ed. London, Arnold.

Halliday, M.A.K. \& Matthiessen, C.M.I.M. (2014). An introduction to Functional Grammar. $4^{\text {th }}$ ed. Routledge. London and New York.

Hoàng Văn Vân (2012). An Experiential Grammar of the Vietnamese Clause. Ha Noi: Viet Nam Education
Publishing House.

Nguyễn Đình Hòa (1997). Vietnamese. Amsterdam: John Benjamins.

Nguyễn Thị Tú Trinh, Phan Văn Hòa, Trần Hữu Phúc (2017). "Some suggestions on how to identify and classify behavioral processes in English and Vietnamese". VNU Journal of Foreign Studies, 33(3), p 120-132.

Nguyễn Văn Hiệp (2009). The history of approaches in describing Vietnamese syntax. Osaka: Osaka University Knowledge Achive.

Saussure, F.D. (1959). Course in General Linguistics. Ed. Charles Bally and Albert Sechehaye. Trans. Wade Baskin. New York: Philosophical Library.

Thái Minh Đức (1998). A Systemic Functional Interpretation of Vietnamese Grammar. Unpublished $\mathrm{PhD}$ dissertation. Department of Linguistics, Macquarie University, Sydney, Australia.

Thompson, L.C. (1965). A Vietnamese Grammar. Seatle and London: University of Washington Press.

\section{Data sources}

Nam Cao (1957). Chí Phèo. Hà Nội: Nxb Văn học.

Nam Cao (1956). Sống mòn. Hà Nội: Nxb Văn học.

Tô Hoài (1941). Dé mèn phiêu luu ký. Hà Nội: Nxb Kim Đồng.

Ma Văn Kháng (1985). Mùa lá rụng trong vườn. Hồ Chí Minh: Nxb Trẻ.

Thạch Lam (1938). Hai đứa trẻ. Truy cập ngày 24.09.2015. https://www.sachhayonline.com/tuasach/truyen-ngan-thach-lam/hai-dua-tre/30

Thạch Lam (1938). Bên kia sông. Truy cập ngày 24.09.2015. https://truyentinhyeu.mobi/truyen-benkia-song-tac-gia-thach-lam/.

Ngô Tất Tố (1937). Tắt đèn. Hà Nội: Nxb Văn học.

Vũ Trọng Phụng (1938). Tuyển tập Vũ Trọng Phụng Tập 1. Hà Nội: Nxb Văn học.

http://vanhaiphong.com/tac-pham/414-xa-kia-ch-p-nhtlang-truyn-ngn-ca-t-duy-anh.html

https://ngnnghc.wordpress.com/2011/01/08/ d\%E1\%BB\%99ng-t\%E1\%BB\%AB/ 


\title{
CÁC CÁCH TIẾP CÂN ĐỬƠNG ĐẠI TRONG PHÂN TÍCH CÚ ĐƠN TIÊNG VIẸTT
}

\author{
Nguyễn Thị Tú Trinh ${ }^{1}$, Phan Văn Hòa ${ }^{2}$, Trần Hữu Phúc ${ }^{3}$ \\ ${ }^{1}$ Khoa Tiếng Anh, Truờng Cao đẳng Giao thông vận tải II, \\ 28 Ngô Xuân Thu, Liên Chiểu, Đà Nã̃ng, Việt Nam \\ ${ }^{2}$ Khoa Đào tạo quốc tế, Đại học Đà Nã̃ng, 41 Lê Duẩn, Quận Hải Châu, Đà Nã̃ng, Việt Nam \\ ${ }^{3}$ Truò̀ng Đại học Ngoại ngũu, Đại học Đà Nã̃ng, \\ 131 Luơng Nhũ Hộc, Phường Khuê Trung, Quận Cẩm Lệ, Đà Nã̃ng, Việt Nam
}

Tóm tắt: Cú với tư cách là một phạm trù ngữ pháp đã và đang là trung tâm thu hút sự chú ý của các nhà ngôn ngữ học Việt Nam, và gây rất nhiều khó khăn cho việc phân tích và giải thích. Đã có nhiều nỗ lực để làm sáng tỏ vấn đề này. Tuy nhiên, chưa có sự đồng thuận giữa các nhà Việt ngữ về phân tích và giải thích cú đơn bởi vì mỗi nhà nghiên cứu dường như phân tích cú theo một cách tiếp cận khác nhau, sử dụng các khung lí thuyết khác nhau. Trong bài báo này, chúng tôi nghiên cứu một số cách tiếp cận hiện đại chính yếu trong việc phân tích cú đơn Việt Nam kèm theo đánh giá có phê phán từng cách tiếp cận để cung cấp cho độc giả một cái nhìn tổng quan về các nghiên cứu cú trong tiếng Việt. Nghiên cứu cho thấy hiện tại, các cách tiếp cận cấu trúc chịu ảnh hưởng bởi các nhà nghiên cứu theo chủ nghĩa cấu trúc châu Âu và châu Mĩ như de Saussure và Bloomfield, và các cách tiếp cận chức năng chịu ảnh hưởng bởi ngữ pháp chức năng của Dik và ngữ pháp chức năng hệ thống của Halliday dường như là các mô hình ngữ pháp chi phối các cách phân tích cú đơn trong tiếng Việt.

Từ khoá: cách tiếp cận đương đại, cách tiếp cận theo cấu trúc, cách tiếp cận theo chức năng 